\title{
1.2 Sport in the present era
}

Abstract. The article analyzes the issue of gender policy value in student sports.

The structural components of gender competence of students in choosing a sport are revealed.

A selection system of sports in higher education institutions has been developed.

The value of sports for self-expression is defined.

It is shown that gender equality has been achieved in sports and it is the natural process of development of human civilization, sportsmen with a large number of human characteristics choose only those that are identified in a particular sport as acceptable to men and women.

It is proved that the system of education and sports can be separated in the formation of values of gender policy among the students.

Keywords: gender policy, sports, students, components, development, selfexpression, gender equality.

Анотація. У статті проаналізовано питання цінність гендерної політики у студентському спорті. Розкрито структурні складові гендерної компетентності студентів у виборі виду спорту.

Розроблено систему вибору видів спорту у закладах вищої освіти. Визначено цінність видів спорту для самовираження.

Показано, що у спорті досягнуто гендерної рівності і це є закономірним процесом розвитку людської цивілізації, спортсмени 3 великої кількості людських характеристик вибирають лише ті, які визначені у конкретному виді спорту які прийнятні для чоловіків і жінок.

Доведено, що система освіти та спорт можуть бути відокремлені у формуванні цінності гендерної політики серед студентської молоді.

Ключові слова: гендерна політика, спорт, студенти, компоненти, розвиток, самовираження, гендерна рівність.

Introduction. Sport as a social phenomenon is an important component of human education. Its origin can be classified as the beginning of human society. Sport 
has long had its place in the formation of society and the human. This is motivated by efforts to achieve the best performance and leads a person to a high mobilization of physical and mental strength, overcoming obstacles and improving physical fitness.

The development of modern theory of sports training is currently impossible without knowledge of psychology, pedagogy, biological sciences of man: anatomy, histology, biochemistry, physiology, biomechanics, which in the XXI century have accumulated great scientific potential for such a phenomenon as sports. The achievements of these sciences must be combined into a single model of the human body, which operates in training and is the main subject of study in the theory of sports training. This holistic theoretical model of man (cells, tissues, organs, organ systems, body) should guide specialists in physical culture and sports, the choice of methods of scientific knowledge of sports by different groups [27].

The problems of professional training of future specialists in physical culture and sports in modern conditions are due to the need to overcome a number of contradictions that arise between the requirements of society and the training of future specialists and their qualifications. Empirical research methods reveal the problem of low public awareness of the importance of sports in human life; also the lack of a childcentric approach to physical education in schools and free educational institutions of various degrees, insufficient attention to the dual approach has led to a decline in interest in sports. There is also no motivation to play sports, because not everyone has information about the benefits of physical activity and methods of self-exercise in shaping the health of each person in particular.

Based on the theoretical analysis of the scientific literature, the conclusion is substantiated that the concept of gender approach to professional training of future specialists in physical education and sports is aimed at forming the semantic paradigm of the future specialist of physical education and sports in the pedagogical environment of higher education. The future specialist in physical education and sports is considered as a person who purposefully acquires qualifications in HEI in accordance with a certain educational level in the process of specially organized educational activities aimed at preparing for further professional activities to maintain the appropriate level 
of higher sports results at the Olympic, global or regional arenas in team or individual dimensions[22].

Professional training of future specialists in physical education and sports is

considered as a process that reflects scientifically and methodically sound measures of free economic education aimed at forming during the training level of professional competence of the individual, sufficient for physical education of different segments of the population and successful work in all sports. taking into account the modern requirements of the labor market.

Modern society exposes its rights and responsibilities for the formation of a healthy person. Changes in the views of young people lead to the distribution of functions among the members of society. Gender policy has its advantages and disadvantages. Gender determines affiliation of a person to one of the social communities. Sport is one of the means of formation of healthy person. Gender policy in sports is determined not only by kinds of sports but also other features[30].

The issue of gender equality is not new for Ukraine, but it is still relevant. Unfortunately, it should be noted that many areas of socio-economic life of the country have discrimination on the grounds of sex. Therefore, gender policy has a positive shift in sports. The result of socio-economic transformations of Ukrainian society was the depolarization of traditional social roles of women and men. There is a large number of scientific studies that prove that a woman differs from a man not only in biological characteristics but also in personal characteristics, thinking, imagination, which affects the sporting achievements of women. The changes that have taken place in the attitude towards women during sports have a long history. Sport as a social phenomenon provided an opportunity to realize their own abilities for both men and women.

The basis of higher education is the priority on personal orientation and on development of personality as a subject of one's own life, creative, self-sufficient person who meets the relevant principles of the gender approach to the process of physical education.

The implementation of a gender approach in physical culture and sports is an important component of bringing the system of physical education in line with 
European requirements. The integration of a gender approach in the system of physical education is necessary not only for compliance with international and national laws and the introduction of gender ideology in sports[20].

It is important to implement the gender approach in physical activity of students, which is seen as an activity that contributes not only formation of physical, moral and mental qualities of the person, but also helps to identify ways of formation in the educational process of psychological differences between persons of different sexes, determine the role of physical activity in gender socialization.

The aim of the study. Uncover the value of gender policy in student sports.

Research methods. Observation of participation in competitions. Analysis of different sports. Distribution of sports by gender.

Physiological features, psychological abilities and inclinations determine choice of sport.

Testing students helps to determine the system of sports selection.

Analysis of research and publications. Gender policy as integral component of formation of competence of students considered many Ukrainian and foreign researchers I. Zaiganov (2007), O. Kikinezhdi (2003), L. Kovalchuk (2008).

The formation of gender culture of university students studied O. Vasylchenko (2008), G. Kondratska (2017), O. Kulish (2009).

The scientist S. Shcherbyna (2016) in her works covers the gender approach in educational process.

The specifics of the gender approach in the educational process in higher educational institutions considered M. Gogol-Savriy (2011), T. Doronina (2012), Yu. Ivchenko (2012), R. Lionchuk (2010).

Gender aspect of formation of values of physical training of students in higher educational institutions are described by O. Marchenko (2013), L. Mazur (2005), A. Chepelyuk (2017).

Research results. The gender approach in professional training is characterized by a rather complex content and structure and includes psychological, scientifictheoretical, practical, psychophysical and physical readiness. And the professional 
profile of the coach includes: knowledge of the properties and characteristics of the athletes; features of psychological and pedagogical, special and physical training of athletes; requirements for their professional culture. These components are closely interrelated and require a gender perspective in the model of the athlete's personality[12].

In our opinion, the gender approach should take into account the gender characteristics of sportsmen / girls and sportsmen / boys. These are gender characteristics that are observed in adolescence of girls, boys: weight, height, physiological and psychological differences. Of particular importance is the development of gender identity and modeling of training plans for physical activity of the individual, choosing the principles, forms, methods and means of implementing the planned amount of training[14].

The gender approach in the training process is essentially individual, in other words, one that will allow the sportsman to reveal his identity. It provides a person with greater freedom of choice and self-realization, helps the child to be perfect and be able to use possible ways to achieve sports results. Assimilation of gender-role representations by the individual occurs through the categorization of a certain cognitive structure - a gender sheme that organizes and directs the perception of the individual.

Sportsmen with a large number of human characteristics choose only those that are identified in a particular sport as acceptable to men and women.

Gender education takes place in the student sports. Gender competence of students is necessary for the choice of type of sports, which motivates the student to regular training.

The definition of "competence" as fundamental is given in a number of various international documents, we have considered several options definition of competence to be interpreted:

- as the ability of the individual to perceive and respond to individual and social needs; set of attitudes, values, knowledge and skills (International Commission of the Council of Europe); 
- also the ability to apply knowledge and skills in new situations (experts of the European Union);

- a combination of knowledge, skills, values and attitudes necessary for daily life (UNESCO);

- ability to perform activities in a qualified manner (IDSLAE - International Department of Standards of learning, achievement and education)[16].

The gender approach as a methodological tool of analysis is substantiated by us as a certain social mechanism of involvement of the athlete's personality in the existing gender distribution of the formation of the training system, appropriate individual-typological argumentation, as well as a certain technology of physical activity distribution and high sports achievements.

The content of the gender approach is the realization that social, anatomical, physiological phenomena affect men and women in different ways, cause different reactions. The gender approach offers another way of cognition the reality of nongender, physiology and nature, but gender determines the psychological qualities, abilities, activities, interests, needs, occupations of girls and boys. The formation of these differences takes place through socialization, personality formation, through physical culture and sports, legal and ethical norms of a particular society[17].

For physical culture and sports, the existing biological differences are not decisive, but are the basis for the formation of male and female personality.

Gender approach in sports is one of the conceptual principles that requires changing the traditional vector of action - not to reduce the real diversity of boys / girls to the same typologies of male / female, but to understand the manifestation of options differently tolerate physical activity, respond to victories and failures, helps to determine an individual approach. The gender approach does not reject the differences between women and men, considers gender as a product of socialization of the individual, which is formed during life in interaction with various social institutions.

The study suggests that men and women do not always have the same views and needs. Each of them has a different attitude to sports. Women are more persistent and systematic, men are more resilient and bold. Therefore, it should be noted that the 
outlined personal qualities may belong to both women and men.

In the context of the problem of our study, the use of post-classical methodology allows us to analyze the gender approach in sports as a system of processes for obtaining high sports achievements by both men and women. In the post-classical approach, the highest credo of cognition of the world is (knowledge-goal), the anthropic principle of knowledge is a means.

The gender approach meets the requirements of modern science, which provide forecasting and planning, both global and local processes, at the level of objective necessity and subjective indirectness[13].

The gender approach in physical culture and sports makes it possible to ensure the effectiveness of men / women quite dynamically.

Gender policy requires the development of a system for the distribution of sports.

The dominance of men in coaching teams can be one of the factors that negatively affects girls' attendance at sports schools. In addition to psychological barriers, opportunities to face sexual harassment and violence, girls may lack successful stories and examples of women's behavior in sports.

At the same time, gender-based leadership and an increase in the number of women coaches can increase the involvement of girls and women in physical education and debate, as well as eliminate gender stereotypes in sports.

On the other hand, it is sport that makes it possible to achieve equality between men and women by establishing common rules and values, such as fair play, nondiscrimination, teamwork, and so on. Involvement of women and girls in sports promotes the development of their leadership skills, independence, activity, competitiveness, self-confidence. All these qualities contribute to the empowerment of girls and women and give them the opportunity to build their professional and family life of their choice. The field of sports includes both professional sports, or highachievement sports, and mass sports, or sports as active recreation and a way to maintain good physical shape. Today, more and more women and men go in for sports to spend their free time and improve their health.

Very often, women's participation in training and sports activities is limited by 
the lack of time, which is associated with a double burden on women - additional work for them to care for children and relatives. It is clear that the lack of accessible social and medical infrastructure and services reduces the free time that women could devote to sports.

Despite the significant increase in the participation of girls and women in sports and the growing audience interested in women's professional sports, there are still significant differences in the coverage of women's and men's activities in the media, where the achievements of male athletes receive much more media attention than achievements of women athletes[19].

Although women have recently been actively involved in sports, there are still some kinds of sport that are characterized as more male or female. Aggressive physical contact is part of men's sports, whereas grace and elegance are the features of a typical female athlete. There are kinds of sport related to stereotypes of masculinity (courage, toughness, strength, aggression in interaction with the opponent), which include various types of martial arts. Whereas femininity need softness, emotionality, artistry (for example, ballroom dancing, figure skating)[26].

But often, women involved in sports characterized as "Masculine", are perceived as "masculine", then as men who are not interested in physical education and sports, are considered as "feminine". On the other hand, it is sport that makes it possible to achieve equality between men and women by establishing common rules and values, such as fair play, non-discrimination, teamwork, etc. Involving women and girls in sports promotes development of their leadership skills, independence, activity, competitiveness, self-confidence[28]'

Note that the classification of sports can be conducted on various grounds. For example, by the nature of the interaction of rival athletes: antagonistic nature (sports in which the opponent responds to the action of the athlete by counteraction); synergetic nature (sports in which the opponent responds to the action of the athlete with a similar action); autonomous nature (sports in which the opponent responds to the action of the athlete by a predetermined autonomous action); complex nature (sports in which the opponent responds to the action of the athlete with different options for their actions in 
the complex). In general, sport forms the will to win, courage, determination, strengthens physical strength, emotional stability.

Therefore, regardless of whether sports represent the image of femininity or masculinity (the main stereotypical differences in sports), sport is considered a man's business: it forms an androgynous type of personality.

These provisions determine the relevance, scientific and practical significance of the fundamental study of the gender approach to the personality of the athlete. Conceptually, it is important to develop psychological concepts of gender development of the athlete, as well as gender-oriented approach to his psychological support, which constitute a holistic gender psychological architectonics of professional development of athletes of both sexes.

Since it is known that there are different divisions of sports into groups: group and individual; cyclic, acyclic, mixed; aerobic and anaerobic, etc.

That is why, according to the results of testing the students of the faculty of physical education in the choice of sports, we came to the following division of sports: men, women and common according the gender equality (Fig. 1).

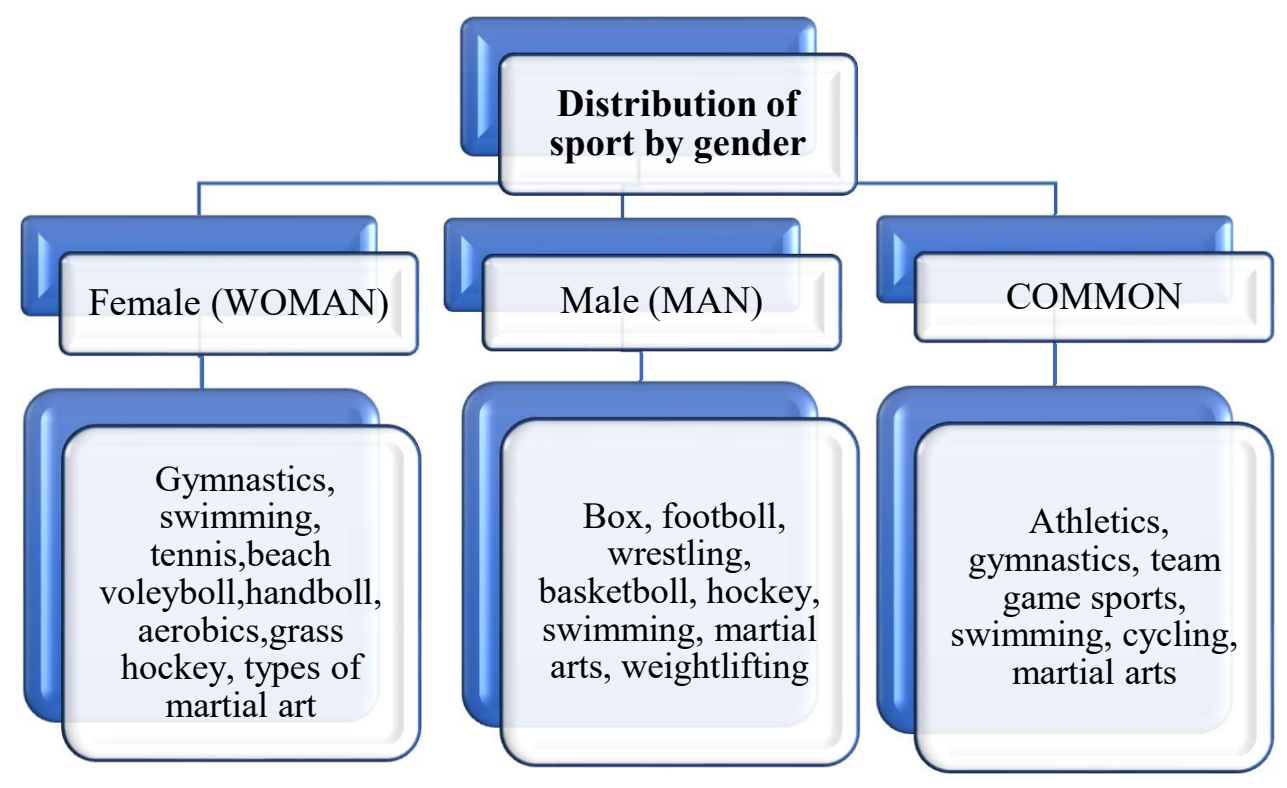

\section{Figure 1. The system of distribution of sports by gender.}

We determine the following main components of gender competence: value- 
personal, cognitive, behavioral, reflexive. Our system is based on the structure of activities of the individual, the structure of key competencies, which are represented in scientific sources.

Foreign researcher I. Zagainov[18] was one of the first to identify gender competence as the basic competence of the teacher represented as the set of knowledge about the essence of the gender approach in education, skills to implement gender strategy in the organization of pedagogical process and experience of using gender knowledge and skills as a basis gender interaction in the educational system.

As we can see, in the given definition lacking such a significant component, as value-personal. In our opinion, it is not just important, but defining, because only under the condition of internalization of gender values the teacher can productively use the gender approach in his own professional activity. In this article, we try to track why the question of gender competence has arisen, why gender values in general appeared on the agenda of social life.

Analyzing the indicators we note popular kinds of sport: aerobics, volleyball, athletics, swimming, gymnastics and basketball. We note that last years it is noticeable girls' interest in such sports as football and various sports is growing martial arts, which are considered as "male" sports. That is why in modern society there is a tendency to expand the scope of girls' interests in sports. In the process of analyzing the results of the survey show that $60 \%$ of boys - play football as the most popular kind of sport and which is considered as "male". Important factor in choosing a sport for boys is its affiliation with men and the interests in certain sports are more stable than for girls. We note that for female students these factors don't have such value. That is why there is an increase in the number of girls who want to do men's sports: football, wrestling and different types of martial arts[13].

The gender culture of the future teacher is a complex concept that includes the formation of personality through the gender awareness, formed personal qualities (egalitarian consciousness, gender sensitivity).

We have identified the criteria of gender culture of the future teacher (Fig. 2). 


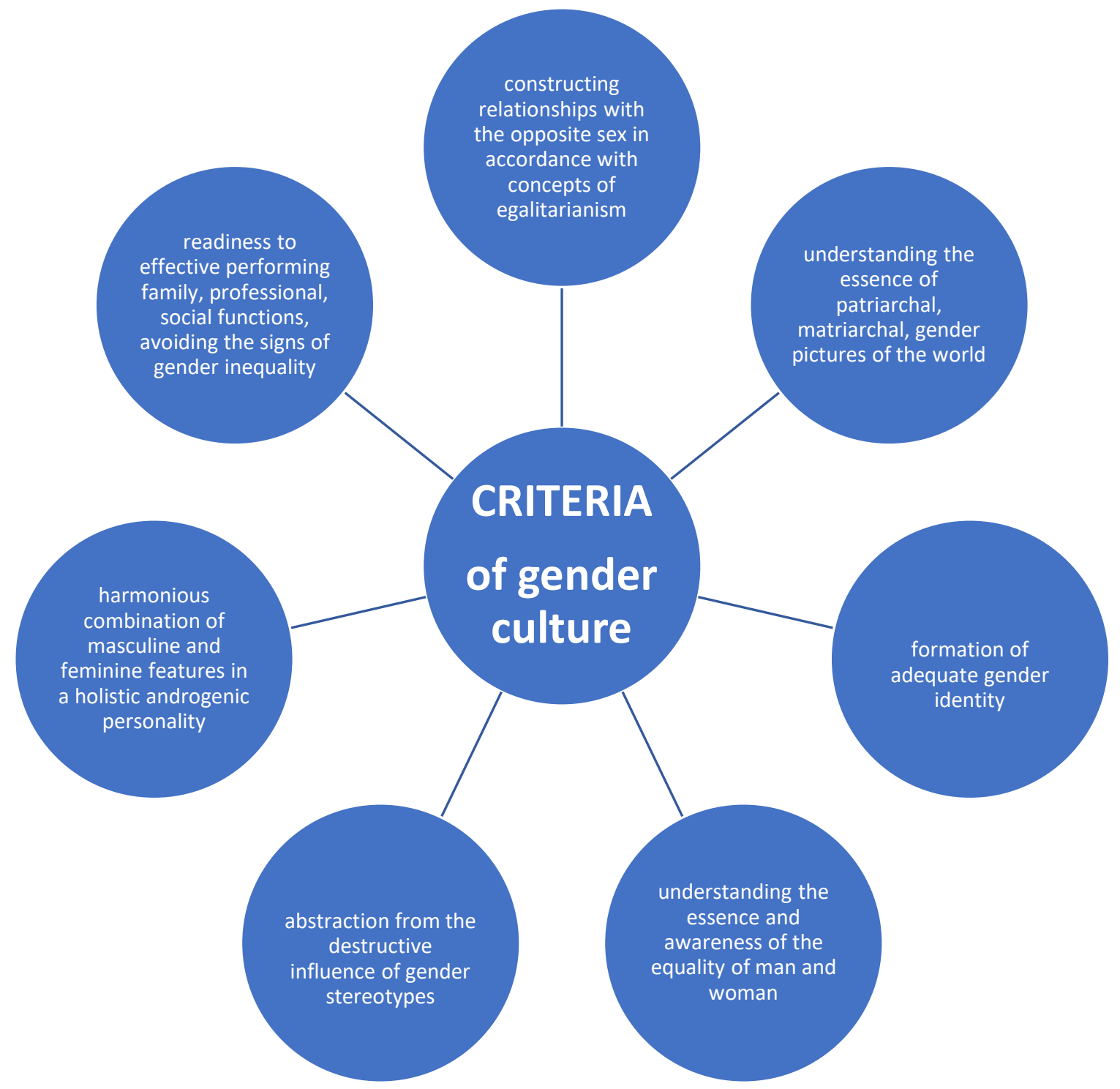

Figure 2. Criteria of gender culture of the future teacher.

Consider each of the selected components of gender competence in more detail.

The value-personal component is determined by the nature of the attitude of future teacher to the problems of gender, which expresses in levels of formation (non formation) of gender sensitivity. The aspect of value is central in the philosophical definition of gender culture. Gender values are the keys to understanding of gender culture in the past and in the present[21].

The reflective component of gender culture provides development and selfdevelopment, realization of reflective ability, promotes the creative approach in professional activity of the specialist and achievement of its efficiency.

The cognitive component provides opportunities to apply a gender approach in their practice on the basis of acquaintance with key concepts of gender ideology, gender 
system of knowledge and formed gender (egalitarian) consciousness [23].

The practical component of gender culture is determined by the degree of formation of the system of skills, which determine the traditional (modern) character of his gender behavior. Definitely it is first of all a system of communicative skills and abilities that allow to establish the level of formation of gender culture of the specialist[27].

Notisable is the fact that this division of the structure of gender culture is largely conditional, but in epistemological terms it is appropriate and justified because it allows a deeper understanding of the essence and structure of the phenomenon of gender culture. It should be noted that all the components are closely connected and interact with each other.

Conclusions. We have made the following assumptions: the value of gender equality in sports is not a phenomenon invented by someone, but a natural result of historical development of human civilization. Values of gender equality in sports will take root in our society gradually with it socio-economic development.

The study proved the relevance of gender equality, which prepares students for adult life. But understanding the values of gender competence of student is still doubtful, this is a great field for the work of all interested and conscious of the importance of such changes. 